\title{
THE SCOTTISH CRIMINAL JURY: A VERY PECULIAR INSTITUTION
}

\author{
PETER DUFF* \\ I \\ INTRODUCTION
}

O ne of the benefits of the comparative study of legal institutions is that it exposes the extent to which they are shaped by contingency as well as by logic or principle. What is regarded in one jurisdiction as the only possible or acceptable way of doing something is often revealed to be pure preconception. In other words, the comparative study of law can act as a balance to the unconscious ethnocentrism often displayed in legal and political ideology. For this reason, the Scottish criminal jury is of particular interest because it embodies several unique characteristics which might seem very peculiar to those familiar with other versions of the institution. In particular, it comprises fifteen persons; its verdicts may be reached on the basis of a bare eight-seven majority; and it has a choice between three different verdicts-guilty, not guilty, and not proven-which even many Scots regard as illogical and unprincipled. The main purpose of this article is to describe and discuss the Scottish criminal jury. I shall also use the above peculiarities and other aspects of the institution to question various assumptions commonly held elsewhere about trial by jury.

II

\section{ORIGINSAND BACKGROUND}

While the exact origins of the Scottish criminal jury are obscure, it is clear that it developed roughly in tandem with, although in a different fashion from, its E nglish counterpart. ${ }^{1}$ It is thought to have derived from the N orman style of government which began to permeate Scotland in the eleventh and twelfth centuries, ${ }^{2}$ although it is likely that there was already some form of community participation in different forums for resolving disputes. ${ }^{3}$ In succeeding centuries, other possible methods of settling conflicts, such as trial by ordeal, trial by combat, and trial by compurgation, died out and trial by jury became more

Copyright @ 1999 by L aw and Contemporary Problems

This article is also available at http://www.law.duke.edu/journals/62L CPD uff.

* Professor of C riminal J ustice, L aw D epartment, A berdeen U niversity.

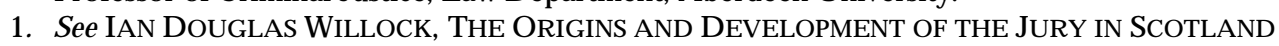
20-30 (1966). This also summarises the E nglish literature on the subject.

2. See id. at 20-21.

3. Seeid. at 5. 
common. ${ }^{4}$ Initially, jurors were selected for their knowledge of the circumstances of the case, but by the fifteenth and sixteenth centuries a distinction began to emerge between jurors and witnesses. By the beginning of the nineteenth century, Baron Hume, regarded as the founder of modern Scottish criminal law, was able to state that jurors had long sat solely in a judicial capacity. ${ }^{5}$

The Scottish civil jury has a less interesting history. ${ }^{6}$ U nlike the criminal jury, it did not emerge spontaneously. While it may have existed in embryonic form in Scottish civil procedure, the modern version was adopted from E ngland in 1815 and consequently possesses none of the peculiarities of its criminal counterpart. ${ }^{7}$ Instead, it is comprised of twelve persons, whose decision originally had to be unanimous but may now be reached by majority, ${ }^{8}$ with the normal choice of two verdicts. A s elsewhere, the use of the civil jury has declined rapidly in recent years, and it was recently observed that many legal practitioners now regard it as a "somewhat exotic creature." ${ }^{9}$ Its use in the Sheriff Court, the lower of the civil courts, was abolished in $1980 .^{10}$ In the higher civil court, the Court of Session, some cases are in theory still tried by jury, most notably actions for damages for personal injuries and for defamation. ${ }^{11}$ In practice, however, there is trial by judge if the parties consent or if "special cause" is shown. ${ }^{12}$ If an action involves complicated questions of law or difficult calculations of damages, this will usually be considered to be sufficiently "special" to justify dispensing with the jury. ${ }^{13}$ A s a consequence of these two exceptions, the number of civil cases heard before a jury each year does not reach double figures. $^{14}$ Thus, the rest of this article is concerned with the jury in criminal cases.

III

THE INCIDENCE OF JURY TRIAL

A t the outset, it is necessary to explain the hierarchy formed by the Scottish criminal courts of first instance: the $\mathrm{H}$ igh Court of J usticiary; the Sheriff Court

\footnotetext{
4. See id. at 21-30.

5. See id. at 197.

6. See id. at 247-57 (discussing the development of the Scottish civil jury).

7. Seeid. at 256.

8. See A dministration of J ustice A ct $\S 11(1)$ (1933) (Scot.). The majority verdict was not introduced to civil procedure until 1933. See id. 251-56.

9. M ark L azarowicz, Excessive D amages and Civil J ury Trial, Scots L A W TIMES (NEWS) 1996, at

10. See L aw R eform (M iscellaneous Provisions) A ct, $§ 11$ (1980) (Scot.).

11. See Court of Session A ct $\S 11$ (1988) (Scot.). Section 11 replaced its outdated counterpart in the Court of Session A ct $\S 11$ (1825) (Scot.), and removed from the ambit of jury trial a large number of types of action which never in practice went to a jury.

12. Seeid. § 9 .

13. See, e.g., Stark v. Ford, 1995 S.L.T. 69,70 (O uter H ouse).

14. See Civil Juries: A bolition?, SCOTS LA W TIMES (NEWS) 1988, at 212; see also A LAN Peterson \& T. St. John BATES, THe Legal Sy Stem OF SCOTLAND 33, 43 (3d ed. 1993); Lazarowicz, supra note 9 .
} 
sitting under "solemn" procedure (that is, with a jury); the Sheriff Court sitting under "summary" procedure (that is, without a jury); and the D istrict Court. The $\mathrm{H}$ igh Court comprises around twenty-five judges who act as the ultimate tribunal for criminal appeals and also form the highest civil court of first instance (the Court of Session). Criminal trials in the $\mathrm{High}$ Court are always heard under solemn procedure by one judge sitting with a jury. The court sits in $E$ dinburgh but goes on circuit as required to the other main towns in Scotland. I ts powers of sentencing are unlimited.

A t the next level, Scotland is divided into forty-nine sheriffdoms, each of which has a sheriff court with one or more sheriffs attached to it depending upon the volume of business. ${ }^{16}$ For example, the Glasgow Sheriff Court has more than twenty sheriffs, whereas the sheriff courts in Orkney and Shetland share one sheriff. Sheriffs, who have both civil and criminal jurisdiction, are appointed from the ranks of long-standing legal practitioners. In criminal matters, sheriffs have a dual jurisdiction. U nder solemn procedure, the sheriff sits with a jury and the maximum sentence he may impose is three years' imprisonment; under summary procedure, the sheriff sits alone, and the maximum sentences available are three months, or six months in the case of a second or subsequent offence of theft or violence, or a fine of $f 5,000 .{ }^{17}$ Finally, there are district courts throughout Scotland where minor criminal cases are heard under summary procedure before one or often more lay justices of the peace. The maximum penalties available to the district court are sixty days' imprisonment or a fine of $£ 2,500$.

A s in most other jurisdictions, the vast bulk of cases are processed through the lower criminal courts. Of all the criminal cases dealt with by the Scottish courts in the year up to M arch 31,1995 , only $2.2 \%$ were heard under solemn procedure and thus offered even the possibility of trial by jury. ${ }^{18}$ A gain, as elsewhere, most accused tend to plead guilty, and only one-third of those solemn cases result in a trial. ${ }^{19}$ Thus, of all those persons prosecuted in the Scottish criminal courts in 1994-95, fewer than one percent put their case to a jury. ${ }^{20}$ In fairness, it should be noted that because of the greater propensity of those prosecuted under summary procedure to plead guilty, jury trials comprised $7.7 \%$ of all trials in Scotland during that period. ${ }^{21}$ N evertheless, this still means

15. See generally ROBERT WEMYSSRENTON \& HENRY HILTON BROWN, CRIMINAL PROCEDURE I 1 1-08 to 1-10, 1-17 (6th ed. 1996), for a full account of the jurisdiction and powers of the Scottish criminal courts. This is the "bible" for Scots criminal lawyers and will frequently be referred to throughout this article.

16. See generally id.

17. See Crime and Punishment A ct $\S 13$ (1997) (Scot.). Though not yet implemented, the A ct increases these maxima to five years' imprisonment under solemn procedure and six months (or 12 months in the case of a subsequent offence of theft or violence) under summary procedure.

18. See 1994-95 Her Majesty's SCOTtish Office, Crown Office and Procurator Fiscal SERV. ANN. REP. 46; see also 1996-97 HER MAJESTY'S SCOTTISH OFFICE, CROWN OfFICE AND PROCURA TOR FISCA L SERV. A NN. REP. 41 [hereinafter collectively CROWN OFFICE REPORTS].

19. See CROWN OfFICE REPORTS, supra note 18.

20. Seeid.

21. Seeid. 
that $92.3 \%$ percent of contested cases were heard either by a sheriff sitting alone or by lay magistrates. ${ }^{22}$ Further, one cannot escape the fact that fewer than one in a hundred of all persons accused of crime in Scotland have their fate determined by a jury, ${ }^{23}$ an astonishingly low proportion given the significance invested in trial by jury and the confidence in the criminal justice system which the institution generates.

\section{A. Jurisdiction}

There are very few crimes which may not be prosecuted under summary procedure. The High Court, where procedure is solemn, has exclusive jurisdiction over the common law crimes of murder and rape (as well as over treason and some other extremely rare offences); thus, those accused of such crimes are always entitled to trial by jury. ${ }^{24}$ A Il other common law crimes, including assault, robbery, burglary, theft, and fraud, may be tried under either solemn or summary procedure and thus need not necessarily be heard before a jury. ${ }^{25}$ For statutory crimes, the relevant legislation sometimes specifies the mode of trial, but very few offences demand solemn procedure. Examples of statutory offences requiring solemn procedure are breaches of the Official Secrets A cts, some terrorist offences and, most commonly, the crime of causing death by dangerous driving. ${ }^{26}$ H owever, the great majority of statutory crimes may be prosecuted only under summary procedure, and thus a jury can never be involved in such cases. ${ }^{27} \mathrm{~F}$ inally, some statutory offences- like most common law offences- may be heard under either summary or solemn procedure. ${ }^{28}$

Where a crime may be tried under either solemn or summary procedure, it is the public prosecutor who decides upon the mode of trial. ${ }^{29}$ A this stage, it should be noted that Scotland has a long-standing tradition of the public prosecution of crime. ${ }^{30}$ G reat importance has always been attached to the independence of the Scottish prosecution service and the fact that it is unaccountable to the police, the courts, the victims of crime, or the accused. ${ }^{31}$ In each and every case, the public prosecutor is "master of the instance," ${ }^{32}$ which means that it is entirely up to the prosecution whether to prosecute at all, what charges to

\footnotetext{
22. Seeid.

23. Seeid.

24. SeeRENTON \& BROWN, supra note 15 , १ १ 1-08 to 1-10, 1-17.

25. Seeid.

26. See O fficial Secrets A cts $\S 10(1911,1989)$ (Scot.); Prevention of Terrorism (Temporary Provisions) A ct, § 13 (1989); R oad Traffic A ct § 1 (1989) (Scot.); R oad Traffic Offenders A ct § 9, sched. 2 (1988) (Scot.).

27. SeeRENTON \& BROWN, supra note 15 , १ १ 1-08 to 1-10, 1-17.

28. Seeid.

29. Seeid.

30. See Susan R. Moody \& J A Cqueline Tombs, Prosecution in the Public InTERest 18-22 (1982); see also J ULIA FIONDA, PUBLIC PROSECUTORS AND DisCRETION: A COMPARATIVE SURVEY 65-95 (1995).

31. See MOODY \& TOMBS, supra note 30, at 18-22; RENTON \& BROWN, supra note $15,93.06$.

32. MOODY \& TOMBS, supra note 30 , at 18-22; RENTON \& BROWN, supra note $15,93.06$.
} 
bring, where to proceed, what procedure to use, and whether to accept a plea bargain. ${ }^{33}$ In determining the appropriate venue and whether to prosecute under solemn or summary procedure, the main factor taken into account by the prosecutor is the adequacy of the sentencing power of the court in light of the seriousness of the crime. ${ }^{34}$ For example, a minor assault, resulting in a black eye for the victim, will almost certainly be prosecuted either in the district court, where the maximum penalty is sixty days' imprisonment, or in the sheriff court under summary procedure, where the maximum penalty is three months. Thus, such cases will not be heard before a jury. On the other hand, a serious assault with a weapon, resulting in severe injuries, will probably be prosecuted before a jury either in the sheriff court under solemn procedure, where the maximum penalty is three years, or the $\mathrm{H}$ igh Court, with its unlimited sentencing power. In this context, it should be noted that recent legislation, not yet activated, enables the sheriff's current sentencing powers under summary procedure to be doubled. ${ }^{35}$ The effect of this is likely to be a further decrease in the number of jury trials.

In Scotland, if a case may be heard under either solemn or summary procedure, the accused has no say in the matter. ${ }^{36}$ This is unlike England and Wales, where, at least with respect to the large number of "either-way" crimes, it is the defendant, and not the prosecutor, who decides whether the case will be tried in the Crown Court before a jury or in the Magistrates Court without a jury. ${ }^{37}$ In the interests of efficiency and the reduction of costs, there have been several attempts in E ngland and Wales to limit the defendant's "right" to opt for jury trial by making various "either-way" offences, primarily petty dishonesty and minor violence, triable only under summary procedure. However, these proposals have been criticised as an attack on citizens' civil liberties and contrary to due process. ${ }^{38}$ In Scotland, on the other hand, the accused has never had any such "right," and perhaps more significantly, there has never been any pressure to grant the accused such an option. ${ }^{39}$ Thus, what in E ngland is often perceived to be a fundamental principle of trial by jury is revealed simply to be the product of the way in which the institution happened to develop in that jurisdiction.

33. See MOODY \& TOMBS, supra note 30, at 18-22; RENTON \& BROWN, supra note $15,93.06$.

34. See MOODY \& TOMBS, supra note 30 , at 18-22; RENTON \& BROWN, supra note 15, 9.06 .

35. The Crime and Punishment A ct $\S 13$ (1997) (Scot.), increases the previous maxima of three and six months to six and 12 months.

36. SeeA ndRew A SHWorth, The Criminal Process: A n E valuative Study 247-48 (1994).

37. See Nicholas Blake, The Case for the J ury, in THE JURY U NDER A TTACK 141 (M ark Findlay \& Peter D uff eds., 1988).

38. See id. at 145-46; see also J ohn J ackson, Trial by J ury and A Iternative Modes of Trial, in CRIMINA L JUSTICE IN CRISIS 255-63 (M ike M CConville \& L ee Bridges eds., 1994); Gerry Maher, Reforming the Criminal Process: A Scottish Perspective, in CRIMINAL J U STICE IN CRISIS, supra, at 62-65. For analysis of this issue, see A SHWORTH, supra note 36, at 242-52.

39. See Thomson Committee, Criminal Procedure in Scotland, Second Report, Cmnd. 6218, ๆ ๆ 51.46-.47 (1975). 
U nlike some jurisdictions, there has been very little pressure in Scotland to curtail the role of the jury in cases involving complex commercial crime. ${ }^{40}$ The prosecutor can always avoid jury trial, of course, by choosing to proceed under summary procedure in the Sheriff Court, but in that case the maximum penalty which can be imposed is only three months' imprisonment (or six months for a second offence) and a fine of $f 5,000$. V arious suggestions to modify or remove the jury from complicated fraud trials were considered by the Thomson Committee in the 1970s, largely because there was concern in England over the issue. $^{41}$ Nonetheless, these proposals were rejected by the majority of respondents to the enquiry and found little favour with the Committee itself. ${ }^{42}$ In a recent review of trial by jury conducted by the Scottish $O$ ffice, the question of juror comprehension was briefly touched upon, ${ }^{43}$ but there was little concern that this posed a particular problem and there were no proposals for change as regards this issue. ${ }^{44}$ This review did not even mention the trial of complex commercial crime, largely because such cases have simply not proved to be a problem in Scotland. It should be noted however, that Scotland has not yet had any long and complex prosecutions of large-scale commercial frauds of the sort that have caused difficulties in other jurisdictions.

\section{B. Citing and E mpanelling the J ury}

In Scotland, every person aged between eighteen and sixty-five is eligible for jury service, subject to various provisos which will be dealt with shortly. ${ }^{45}$ U ntil relatively recently, there was a property qualification, ${ }^{46}$ but this was increasingly ignored in practice and finally abolished in $1980 .{ }^{47}$ Thus, the clerk of the sheriff court now obtains a list of names randomly drawn from the electoral roll and writes to those so chosen, requesting the details necessary to establish whether they are eligible for jury service. ${ }^{48}$ This same procedure is also applicable to any $\mathrm{H}$ igh Court trials which take place in the sheriffdom. ${ }^{49}$

A s in other jurisdictions, various categories of persons are ineligible because of their involvement in the criminal justice system, including members of the judiciary and court staff, legal practitioners, police and prison officers,

40. For example, in England and Hong Kong. See generally FRAUD TRIALS COMMITTEE, RePort; see also Peter Duff et al., JuRIES: A Hong Kong PERSPECTIVe 43-51 (1992); Michael L evi, The Role of the J ury in Complex Cases, in THE JURY U NDER A TTA CK, supra note 37, at 95-111.

41. See ThOMSON COMMITTEE, supra note 39, १ी 51.34-.41.

42. Seeid.

43. See SCOTTISH OfFICE, JURIES AND VERDICTS, 1994, १ी 4.1-.4 [hereinafter JURIES AND VERDICTS].

44. See SCOTTISH OfFICE, FIRM AND FAIR, 1994, Cmnd. 2600 [hereinafter FIRM AND FAIR]. The jury proposals are in chapter 3.

45. See Law R eform (M iscellaneous Provisions) A ct $\S 1$, sched. 1 as amended (1980) (Scot.) for jury ineligibility and disqualification rules.

46. See J uries A ct $\S 1$ (1825) (Scot.).

47. See L aw R eform (M iscellaneous Provisions) A ct, sched. 3 (1980) (Scot.). A similar reform had taken place in E ngland and Wales some 10 years earlier under the Criminal J ustice A ct $\S 25$ (1972).

48. SeeRENTON \& BROWN, supra note 15 , ๆ 15-07.

49. Seeid. 
procurators fiscal and their staff, and various types of social workers involved with the juvenile justice system and probation schemes. ${ }^{50} \mathrm{~A}$ more recent category of persons disqualified are those who have at any time been sentenced to five years' imprisonment or more, or who have received a sentence of three months and have not yet been rehabilitated under the R ehabilitation of $O \mathrm{f}$ fenders A ct of $1974 .{ }^{51}$ A $n$ even more recently added disqualification was for anyone on bail for any offence. ${ }^{52}$ Further, persons suffering from serious mental disorders are disqualified from jury service. ${ }^{53}$ Finally, in order to ensure that potential jurors have a sufficient grasp of the English language, the statute stipulates that they must have been resident in the $U$ nited $K$ ingdom for any period of at least five years since attaining the age of thirteen. ${ }^{54}$

Certain other groups of persons are entitled to be excused from jury service of right, due to the social value of their occupations. These include doctors, dentists, nurses, pharmacists, and veterinarians, members of the armed forces, ministers of religion and those in holy orders, and members of the $U$ nited $\mathrm{K}$ ingdom and $\mathrm{E}$ uropean parliaments. ${ }^{55}$ Those who have attended for jury service within the last five years are also entitled to be excused of right. ${ }^{56}$ Finally, any potential juror may seek to be excused for good reason, for example, if they are suffering from a serious long-term illness making their attendance at court impossible. ${ }^{57}$

A s a result of the various disqualifications and exemptions, there has been recent concern that juries are not as representative of the community as they might be. These concerns led to consideration of the problem of "juror attrition" in a general consultation paper on the jury issued by the Scottish O ffice. ${ }^{58}$ The suggestion was that the procedures for selecting and contacting jurors from the electoral roll were not working as well as they might, and more significantly, that larger proportions of potential jurors from the middle and upper socio-economic groups were disqualified or being excused from jury service. ${ }^{59}$ A study carried out for the consultation paper demonstrated that of 11,806 members of the public in E dinburgh eligible to serve on the jury, contact was made with only 7,500 (sixty-eight percent) by the sheriff clerk. ${ }^{60}$ Of these, 2,520 were statutorily excluded, 1,560 were excused, and, ultimately, only 3,283 (thirty percent) were present in court as potential jurors. ${ }^{61}$ F urther, thirty-eight

\footnotetext{
50. See L aw R eform A ct, sched. 1, pt. 1 (1980) (Scot.).

51. Seeid. pt. 2.

52. See Criminal J ustice A ct $\S 7$ (1995) (Scot.).

53. See L aw R eform A ct, sched. 1, pt. 1 (1980) (Scot.).

54. SeeRENTON \& BROWN, supra note 15 , १ 15-01.

55. See L aw R eform A ct, sched. 1, pt. 3 (1980) (Scot.). M ore cynical readers might question the inclusion of the last listed group as socially useful.

56. Seeid.

57. See L aw R eform (M iscellaneous Provisions) A ct $\S 1(5)$ (1980) (Scot.).

58. SeeJ URIES A ND VERDICTS, supra note 43, १ 3.35.

59. Seeid. app. 1, at 48 .

60. Seeid. app. 1, at 49.

61. Seeid. ๆ $93.27-.28$.
} 
percent of potential jurors from the upper socio-economic group were excused compared with eighteen percent and twenty-three percent from the bottom two groups. $^{62}$ This paper led to proposals for reform in a government White Paper on criminal justice, ${ }^{63}$ and legislation was then enacted to try to reduce the level of "attrition" and make it more difficult to secure an excusal on the ground of inconvenience. $^{64}$

O nce eligibility has been established, a list of potential jurors is drawn up and the sheriff clerk summons sufficient persons when a trial is about to take place. ${ }^{65}$ The resulting "list of assize" is kept in the clerk's office and, upon application, a copy is available without charge to the defence. ${ }^{66} \mathrm{U}$ ntil very recently, the list of assize had to state the occupation of the prospective jurors, but following a recommendation which resulted from the recent review of the jury, ${ }^{67}$ this requirement was removed and the list now records only jurors' names and addresses. ${ }^{68}$ The reason for this was that while jurors' occupations were thought to form the basis for many peremptory challenges, occupation alone was not thought sufficient to justify any challenge for cause upon the abolition of peremptory challenges. ${ }^{69}$ Therefore, there was no "substantive reason" for jurors' occupations to be revealed. ${ }^{70}$ The jurors are selected by ballot in open court from those potential jurors who have appeared at court in response to being cited. ${ }^{71}$

\section{Questioning of J urors and Challenge for Cause}

There is no equivalent to the voir dire procedure in Scotland, a fact which might surprise some A merican readers. The strong opposition of the Scottish criminal justice system to any procedure of this type is well illustrated by the observations of the A ppeal Court in M cCadden v. H . M . A dvocate: ${ }^{72}$

There may never be a process which eliminates the possibility of personal prejudices existing among jurors, the nearest practical one (and it is not foolproof) being possibly the "vetting" of jurors, a system against which the law of Scotland has steadfastly closed the doors. E vidence of how it is used and abused in countries in which it is operated only tends to confirm the wisdom of that decision. ${ }^{73}$

The court went on to observe that it should not be "lightly assumed" that jurors will pursue their prejudices in defiance of their oath and the directions of

\footnotetext{
62. Seeid. app. 1, at 51 .

63. See FIRM AND FAIR, supra note 44 , ch. 3.

64. See C riminal J ustice A ct $\S \S 6,7$ (1995) (Scot.).

65. SeeRENTON \& BROWN, supra note 15 , ๆ 15-10.

66. See id. १ 15-08.

67. See JURIES AND VERDICTS, supra note 43, ๆ 3.35; see also FIRM AND FAIR, supra note 44, ๆ 3.11 .

68. See C riminal J ustice A ct $\S 6$ (1995) (Scot.).

69. For a discussion of challenges, see infra Parts III.C-D .

70. FIRM AND FAIR, supra note 44, ๆ 3.11.

71. SeeRENTON \& BROWN, supra note 15 , ๆ 18.34 .

72. 1985 J.C. 98 . The opinion was given on behalf of the court by the Lord J ustice Clerk, Scotland's second most senior judge.

73. Id. at 102.
} 
the judge. ${ }^{74}$ On a more practical note, the court pointed out that the broad base from which jurors are drawn means that any prejudices and biases tend to cancel each other out, and further, that the majority verdict, whereby a bare eightto-seven vote either way suffices, ensures that it is unlikely that one prejudiced juror can affect the outcome of the case. ${ }^{75}$

A s a consequence, there may be no general questioning of potential jurors by the judge or by any of the parties to the case. The total antipathy of the Scottish legal system to any form of voir dire is also illustrated in M. v. H. M. A dvocate. $^{76}$ This case involved terrorist offences which had spilled over from N orthern I reland to Scotland. ${ }^{77}$ A the request of one of the defence counsel, potential jurors were asked by the judge whether they had lost any near relatives in the religious and political disturbances in N orthern I reland which might affect their ability to give unbiased consideration to the issues involved. ${ }^{78} \mathrm{~A} \mathrm{~s}$ it happens, no jurors declared themselves to be in this position. ${ }^{79}$ During the course of an appeal based on other grounds, however, the A ppeal Court stated that they did not approve of this procedure:

$[T]$ here should be no general questioning . . of persons cited for possible jury service to ascertain whether any of them could or should be excused from jury service in a particular trial .... The essence of the system of trial by jury is that it consists of fifteen individuals chosen at random from amongst those who are cited for possible service. $^{80}$

Further, most views presented to the Thomson Committee on Criminal Procedure, which reported shortly after the above case, were also opposed to any kind of investigation of jurors' attitudes. ${ }^{81}$

Challenges for cause are permissible, but because such challenges are very rare, no clear procedure has evolved for dealing with them. ${ }^{82}$ It has al ways been regarded as sufficient cause for challenge if a potential juror is clearly disabled in some way, for example, if he is insane, deaf, dumb, or blind, ${ }^{83}$ but further development of this area of law has obviously been severely limited by the attitude to questioning jurors. It is difficult to challenge a juror for cause if one has no information about that juror beyond a name and address or, formerly, an occupation. Further, it has been held that

[i]t is not a sufficient cause for a juror to be excused that he is of a particular race, religion, or political belief or occupation, or indeed that the juror might or might not

74. Id.

75. See infra text accompanying note 131 .

76. 1974 S.L.T. (N otes) 25 (H.C.J.). These observations were made by the Lord J ustice General, Scotland's most senior judge, in the course of giving the court's opinion.

77. Seeid.

78. Seeid.

79. Seeid.

80. Id.

81. SeeThom son Committee, supra note $39,951.27$.

82. Seeid. ๆ 51.23 .

83. SeeRENTON \& BROWN, supra note 15 , ๆ 18.36 . 
feel prejudice one way or the other towards the crime itself or to the background against which the crime has been committed ${ }^{84}$

On the other hand, it is regarded as sufficient cause if a potential juror has a personal connection with one of the parties to the case or has personal knowledge of the facts. ${ }^{85}$ In order to ensure that such jurors are identified, before the case is called, the clerk tells potential jurors the names of the accused, the complainant, and anyone else named in the indictment and indicates that if they know any of these persons, they should make this known. ${ }^{86}$ O nce the jury has been empanelled, the judge may remind the jurors that if they know any of the parties involved or feel that there is any reason why they should not serve on the jury, they should make this known to the court immediately. ${ }^{87}$

In essence, however, it can be seen that the philosophy underlying jury selection in Scotland, as well as in E ngland and W ales, is very different from that governing the process in the U nited States. In Scotland, there is a very strong view that the accused, and the prosecutor, must simply accept the jurors who emerge randomly from the selection process. The feeling is that the prejudices and biases of the various individuals comprising the jury will assume little significance in the dynamic of group decisionmaking, particularly when a bare majority suffices. There is a lot to be said for this point of view. The complete lack of information about prospective jurors means that no attempt can be made by either side to "stack" the jury in its favour. Further, the simplicity of the selection procedure helps to ensure that the jury really does represent the community, although this of course means that any prejudices generally held in the community are likely to be replicated in the jury room. In practical terms, the absence of any kind of voir dire procedure also renders trial by jury quicker and cheaper than on the other side of the A tlantic.

In conclusion, it is once again significant that what is perceived to be an integral part of the institution of trial by jury in one group of related jurisdictions is regarded with abhorrence in a different group of jurisdictions. It is clear that these views are shaped by specific histories and cultures rather than deriving logically and necessarily from the principles which support trial by jury.

\section{Peremptory Challenge}

In Scotland, the right of peremptory challenge has gradually disappeared. The position was formalised in the early nineteenth century when the accused was granted five peremptory challenges, ${ }^{88}$ but the number was reduced to three

84. See M. v. H. M. A dvocate, 1974 S.L.T. J 25 (H.C.J).

85. See Pullar v. H. M. A dvocate, 1993 S.C. (J.C.) 126, 134-35 (1993).

86. Seeid. at 134.

87. Seeid. at 135.

88. See Jurors A ct $\S 16$ (1825) (Scot.); WILLOCK, supra note 1, at 193. However, ALBERT V. SHEEHAN, CRIMINAL PROCEDURE I 1.42 (1990), states that the right of peremptory challenge was formalised in the Jurors in Criminal Trials A ct $\S 1$ (1822) (Scot.). The last manifestation of this right was in the Criminal Procedure A ct $\S 130$ (1975) (Scot.). 
in $1980,{ }^{89}$ and abolished altogether in $1995 .^{90}$ Three reasons have been cited to justify this whittling away of the peremptory challenge. First, it was sometimes argued that such challenges increased the overall inconvenience to the public of jury service because additional jurors had to be cited to cater for the possibility of such challenges, particularly in cases involving several accused. ${ }^{91}$ Second, it was frequently alleged that good citizens, who were willingly attempting to fulfil their civic duty, were puzzled, embarrassed, or even angered by being challenged in open court for reasons they simply did not understand. ${ }^{92}$ B oth these arguments have some validity. The third and most influential argument, which clinched the abolition of the peremptory challenge, was the allegation that this opportunity was frequently "abused" by the defence in an attempt to secure a jury which was less likely to convict. ${ }^{93}$ It was suggested that prospective jurors were challenged on the basis of sex, occupation, or even dress, the wearing of a suit and tie being regarded as fatal to one's chances of making the jury panel. ${ }^{94}$ It was also claimed that in cases of fraud or financial crime, prospective jurors who seemed likely to be able to understand the facts in the case-for example, accountants or bankers- were routinely challenged. ${ }^{95}$ This argument is based upon two assumptions, and it is worth examining each of these in turn.

First, there is the claim that defence solicitors and advocates regularly "abused" their peremptory challenges in an attempt to secure the type of jury they wanted. ${ }^{96}$ A ssuming that this does amount to "abuse," which of course might well be contested, it is fair to say that there is much anecdotal evidence to support this charge, ${ }^{97}$ although there is virtually nothing in the way of any firm data about the extent and nature of the phenomenon. The government's recent consultation paper admitted as much, stating that "there is no direct evidence of whether and on what scale such abuse occurs," but added that "the procedure clearly has the potential for abuse." 98 of the 994 jurors in the attrition study who were balloted, six percent were challenged, five percent by the defence and one percent by the Crown, and while there was no evidence of any sexual bias in the use of the challenge, it did seem that potential jurors from the upper socio-economic groups were more likely to be challenged by the defence. $^{99}$ It should be noted, however, that the numbers involved were very small. O nly forty-eight jurors from the upper socio-economic group were bal-

\footnotetext{
89. See C riminal J ustice A ct $\S 23$ (1980) (Scot.).

90. See C riminal J ustice A ct $\S 8$ (1995) (Scot.)

91. See J URIES AND VERDICTS, supra note 43, ๆ

92. Seeid.

93. Seeid.

94. See id. १ 3.30.

95. Seeid.; see also Thom Son COMmitTeE, supra note 39, ๆ 51.29 .

96. See J URIESAND VERDICTS, supra note 43, ๆ १ 3.28-.34.

97. Seeid.

98. Id. १ 3.31 .

99. See id. app. 1, 9 10.4, tbl. 10. Of course, this might simply mean that in some cases, men were routinely challenged whereas in others, it was women that were treated in this way, and that these opposing trends cancelled each other out.
} 
loted, eight of whom were challenged (seventeen percent) as against 306 jurors from the next highest socio-economic group, of whom eight percent were challenged. ${ }^{100}$ This hardly seems sufficiently convincing evidence to justify the abolition of a procedure which had formed part of trial by jury for almost two hundred years.

The second step in the argument is that the "abuse" of the peremptory challenges led to an increased likelihood of acquittal. ${ }^{101}$ There is no evidence to support this claim. Such an argument assumes that Scottish defence practitioners, with virtually no information to go on, were successful in predicting the likely reactions of potential jurors to particular cases. E vidence from other jurisdictions suggests that even where there is much more information available about prospective jurors, it is extremely difficult for the lawyers involved to predict their behaviour. ${ }^{102}$ Further, the argument assumes that, even if Scottish practitioners did have some success, three challenges (or previously five) were enough to alter the dynamics of a jury of fifteen which may reach a verdict on the basis of a simple majority. Clearly, the role of any individual juror can be much more crucial where there is a requirement of unanimity or some sort of weighted majority. Significantly, some Home Office research carried out in England and $W$ ales before the abolition of the peremptory challenge there on similar unsatisfactory grounds ${ }^{103}$ revealed that the acquittal rate was no higher in cases where the challenge had been used than in cases where it had not. ${ }^{104}$

Therefore, the reasons given for the abolition of the peremptory challenge in Scotland were unsatisfactory. There was little evidence that it was being "abused" and no evidence whatsoever that this "abuse" had any effect on the outcome of cases. This is regrettable because, in my view, there is a perfectly respectable argument of principle which could have been used against the peremptory challenge. Q uite simply, the jury in Scotland is clearly meant to be fifteen people chosen at random from the community, and there is no justification for either side to attempt to alter its composition except where there are grounds for challenge for cause. Furthermore, the existence of the bare majority verdict means that the presence of one biased juror is very unlikely to make any difference to the outcome of the case, unlike the position where there is a requirement of unanimity. $Y$ et this type of argument was rarely advanced by those responsible for the demise of the peremptory challenge in Scotland. The right thing was done for the wrong reasons.

100. Seeid.

101. Seeid. १ 3.30.

102. See Valerie P. Hans \& Neil Vidmar, Judging the JuRy $76-78$ (1986); see also Sean EnRIght \& James MORTON, TAKING Liberties: The Criminal JURy IN THE 1990S, at 63-67 (1990).

103. See Criminal J ustice A ct $\S 118$ (1988) (Scot.). See also ENRIGHT \& MORTON, supra note 102, ch. 4 , for details.

104. See J ulie V ennard \& D avid R iley, The U se of the Peremptory Challenge and Stand by of J urors and Their Relationship to Trial O utcome, 1988 CRIM . L. REV. 731-38. 
Finally, it is interesting to note that the disappearance of the peremptory challenge aroused little reaction in Scotland, whereas in England, its gradual demise caused an outcry and was often portrayed as a serious attack upon the civil liberties of defendants. ${ }^{105}$ A gain, what was often regarded as a fundamental aspect of jury trial in E ngland appears to have been discarded quite easily in Scotland. To some extent, this might be explained by the existence of the requirement for a ten-to-two majority in E ngland, but it probably also reflects the differing ideologies which simply happen to have grown up around the same institution, without much basis for their differences in terms of strict logic.

\section{E . Publicity B efore and D uring the Trial ${ }^{106}$}

E ssentially, all that may appear in the media about a criminal prosecution is a fair and accurate report of legal proceedings, published contemporaneously and in good faith. ${ }^{107}$ The Scottish judiciary takes a very severe attitude toward any potentially prejudicial publicity before or during the trial. While the position is now primarily governed by legislation, it is useful to examine the common law position first. O ne recent example will suffice to demonstrate the stringent approach invariably adopted by the Scottish courts. In M uir v. B ritish Broadcasting Corporation, the BBC was about to broadcast an update of an earlier programme about prisoners being beaten by prison officers in G lasgow's Barlinnie prison. ${ }^{108}$ The programme reported a prison doctor's view that a particular individual's injuries were consistent with his having been assaulted by guards. ${ }^{109}$ The report further revealed that the doctor had been dismissed from the prison service but was being backed by the B ritish M edical A ssociation, and that the E uropean Committee for the Prevention of Torture also believed the prisoner's injuries were consistent with his allegations of mistreatment. ${ }^{110}$ The prison doctor was to be a witness in a trial of three prison officers for assaulting inmates at B arlinnie which was due to start the following month. The charges did not relate to the prisoner featured in the programme, and there was no reference to the accused in the programme nor to the proceedings against them. Nevertheless, on application by the three accused, the High Court banned the programme because there was a "distinct risk that at least one out of the fifteen jurors may get the impression from this programme that Doctor D anson was a witness of considerable credit whose views should be taken to be of great importance."111 The Court observed that the test to be applied in such cases is

105. See Sean Enright, Reviving the Challenge for Cause, 139 NEW L.J. 9-10, 19 (1989); see also TONY GIFFORD, WHERE'S THE JUSTICE: A MANIFESTO FOR LAW REFORM 50-51 (1986); J ames Gobert, The Peremptory Challenge-A n O bituary, 1989 CRIM. L. REV. 528-38; E.P. Thompson, Subduing the J ury, L OND ON REVIEW OF BOOKS, Dec. 4, 1986, at 7-9 \& D ec. 18, 1986, at 12-13.

106. For a discussion of contempt of court in Scotland, see E RIC M. CLIVE ET AL., SCOTSLAW FOR J OURNA LISTS 100-31 (5th ed. 1988).

107. See C ontempt of C ourt A ct $\S 4$ (1981) (Scot.).

108. 1997 S.L.T 425 (H.C.J.).

109. Seeid.

110. Seeid.

111. Id. at 427-28. 
whether there is "more than minimal risk of prejudice." ${ }^{112}$ Thus, either the accused or the Crown may apply to prevent media coverage of not only their own case, but of a much broader range of subjects which might impinge incidentally upon the forthcoming trial.

In terms of statute, the Contempt of Court A ct of 1981 makes it an offence of strict liability to publish, including broadcast, anything which creates a "substantial risk" that the course of justice in any "active" proceedings will be "seriously impeded or prejudiced." ${ }^{113}$ This legislation covers Scotland, E ngland, and Wales, but, as A listair J. Bonnington states, "its application in Scotland is so starkly different from that in England that it is difficult to believe that the two jurisdictions are dealing with the same statutory provisions." ${ }^{114}$ First, the Lord A dvocate, Scotland's senior law officer, is much more likely than his English counterpart, the A ttorney $G$ eneral, to act when there has been prejudicial publicity. ${ }^{115}$ Second, the Scottish courts have interpreted the provision that there must be a "substantial risk" to mean that there must be "some risk, greater than a minimal one," of prejudice. ${ }^{116}$ This rather odd interpretation of the statutory formula means that it is relatively easy in Scotland to allege contempt. ${ }^{117}$ Finally, in Scotland, the accused himself may bring proceedings under the A ct, whereas in England the A ttorney G eneral must either bring or consent to any such proceedings. ${ }^{118}$

B onnington demonstrates the contrasting approaches adopted in Scotland and $E$ ngland with reference to a recent English case, where the A ttorney G eneral refused to take action over what was undoubtedly prejudicial reporting of a trial, on the ground that he thought that contempt proceedings were unlikely to succeed. ${ }^{119}$ B onnington observes that in Scotland the L ord A dvocate would undoubtedly have prosecuted in such a case, and further, that if he had not, the accused could have taken action. ${ }^{120}$ Bonnington's predicted result of such proceedings in Scotland was that "there is little doubt that all newspapers would have been convicted and would have suffered substantial fines-in the case of the Sun ${ }^{[121]}$ editor, a jail sentence would have been quite likely." ${ }^{122}$ In summary, therefore, the strict approach of the Scottish judiciary to the possibility of prejudicial reporting has meant that the media has rarely impinged upon jury

112. Id. at 427 .

113. Contempt of Court A ct $\S 2$ (1981) (Scot.).

114. A listair J. Bonnington, Press and Prejudice, 145 N EW L J. . 1623 (1995).

115. Seeid.

116. H. M. A dvocate v. Caledonian Newspapers L td., 1995 S.L.T. 926, 930.

117. See generally CLIVE ET A L., supra note 106, at 103 , who thought that this was a "new and important" test because it clarified a previously vague standard. However, as events show, this view proved to be unduly optimistic.

118. See Contempt of Court A ct $\S 7$ (1981) (Scot.). This difference reflects the common law position in each of the jurisdictions.

119. See B onnington, supra note 114 , at 1623 .

120. Seeid.

121. The most popular tabloid newspaper in the U nited K ingdom.

122. Bonnington, supra note 114 , at 1623 . 
trial in Scotland. It should be remembered that, unlike in the U nited States, in Scotland there is no constitutional right to freedom of expression or freedom of information to counter-balance the strict laws of contempt.

Despite their draconian attitude toward potentially prejudicial publicity, Scottish judges have not looked sympathetically upon claims made by the accused about the effects of adverse publicity where this has unfortunately occurred. B onnington observes that there has never been a successful application to prevent a trial proceeding because of prejudicial pretrial publicity, nor a successful appeal against conviction based on the grounds of prejudicial publicity. ${ }^{123} \mathrm{He}$ cites in illustration of this claim the rather contradictory case of Stuurman v. H. M. A dvocate, ${ }^{124}$ where the court imposed large fines on the media for "causing 'the greatest risk of prejudice,'"125 and yet only a few weeks later decided that the accused could nevertheless receive a fair trial. ${ }^{126}$ A nother interesting case is $\mathrm{H}$. V. Sweeney, ${ }^{127}$ where the trial proceeded despite overwhelming publicity, including the resignation of the Solicitor General, ${ }^{128}$ the publication of alleged confessions by the accused, and "no fewer than 160 articles" in the media. ${ }^{129}$ The High Court's view was that the admittedly prejudicial coverage of the case was outweighed by the public interest in the prosecution of serious crime, the gap of several months before the trial was to commence, and the beneficial effect upon the jury of a careful direction by the judge not to be swayed by the publicity. ${ }^{130}$

\section{F. The Number of J urors}

The Scottish criminal jury comprises fifteen persons. In the early days of jury trial, the number of jurors was not fixed, although there was always a preference for an odd number because of the existence of the majority verdict. ${ }^{131}$ By the end of the sixteenth century, the jury virtually always comprised fifteen persons. This practice was eventually confirmed implicitly in the J urors A ct. ${ }^{132}$ In the 1970s, the Thomson Committee considered the possibility of a smaller jury. ${ }^{133}$ Its primary concern was whether it was necessary to inconvenience quite so many members of the public, observing that the Scottish civil jury, as

123. Seeid.

124. See id. (relying generally on Stuurman, 1980 J.C. 111, 111-13, 121 (1980)).

125. Id.

126. Seeid.

127. 1983 S.L.T. 48, 55-57 (H.C.J.) (The L ord J ustice-G eneral).

128. Scotland's second most senior law officer.

129. See Sweeney, 1983 S.L.T. at 56; see also Ross HARPER \& ARNOT MCWhINNIE, The GLASG OW RA PE CA SE 139-42 (1983).

130. See Sweeney, 1983 S.L.T. at 56-57.

131. See WILLOCK, supra note 1 , at 184-90.

132. $\S \S 7,17$ (1825) (Scot.); see WILLOCK, supra note 1, at 189.

133. See Thom SON COMMITTEe, supra note 39, ๆ 51.12. The Committee stressed that this recommendation was dependent upon the retention of the three verdict system. For a discussion of this, see infra Part III.I. 
well as criminal juries in other jurisdictions, operated with fewer jurors. ${ }^{134} \mathrm{Al}$ though the committee was not impressed with the argument that a slightly smaller jury was less likely to provide a representative cross-section of the population, dismissing this as "speculative," 135 it nonetheless concluded that the number of jurors should be reduced to twelve, with a simple majority of seven votes being necessary for a guilty verdict. ${ }^{136} \mathrm{H}$ owever, this recommendation was not acted upon. The more recent Scottish Office review also raised the question of unnecessary inconvenience to citizens and asked for views on the reduction of the size of the jury to eleven, twelve, or thirteen persons. ${ }^{137}$ M ost of those who responded were not in favour of any change and thus, the number of jurors was left at fifteen. ${ }^{138}$ B oth the Thomson Committee and the Scottish O ffice review emphasised that the size of the jury could not be looked at in isolation and was bound up with the majority required for a verdict and the three verdict system. ${ }^{139}$ Consequently, I shall return to the number of jurors when these issues are discussed below.

G. M anagement of the J ury ${ }^{140}$

A fter the jury has taken the oath, there must be no communication on the subject of the trial between a juror and nonjuror. If this rule is broken, the trial is not necessarily abandoned, nor is any conviction necessarily quashed. The consequences of the infringement depend very much on the circumstances, in particular the severity of the breach and its potential to prejudice the trial. If the infringement is minor, it may not be necessary to excuse the juror and a direction by the judge to the jury may suffice. A Iternatively, the juror may be excused and the trial may continue. However, if the breach is particularly serious and there is a danger that it may prejudice the whole jury, it may well be necessary to abandon the trial. W here a trial is adjourned overnight, the jury is not secluded (that is, sequestered) except in the most exceptional of cases. O nce the verdict is being considered the matter is entirely different, and the jury must be secluded. ${ }^{14}$

If a juror becomes ill during a trial or is excused for some other reason, the trial may continue provided that there are not less than twelve jurors remaining. ${ }^{142}$ In such cases, a majority of eight jurors is still required to return a guilty verdict; otherwise the result must be acquittal. ${ }^{143}$ There is no provision in Scot-

134. SeeThom Son Committee, supra note 39 , 151.08 .

135. Id. ๆ 51.11.

136. Seeid. ๆ 51.13.

137. See J URIESAND VERDICTS, supra note 43 , ११ 5.1.-.4.

138. SeeFIRM AND FAIR, supra note 44, ๆ $3.20,3.21$.

139. See J URIESAND VERDICTS, supra note 43, १ๆ 5.1-.4; THOMSON COMMITTEE, supra note 39, ๆ 51.12 .

140. The following section is based very closely on RENTON \& BROWN, supra note 15, १ १ 18.42-.45, where all the necessary citation of the statutory provisions and cases will be found.

141. See infra notes 151, 152 and accompanying text.

142. SeeRENTON \& BROWN, supra note 15 , १ १ 18.42-.45.

143. Seeid. 
land for alternate jurors. Such a provision has not as yet proved necessary because trials rarely last for more than a couple of days and up to three jurors may be lost without the trial having to be abandoned. ${ }^{144}$

It is worth noting that in Scotland there are no opening statements by the lawyers. Instead, jurors are given a copy of the indictment, which comprises a narrative of the essence of the case against the accused. ${ }^{145}$ Immediately after the prosecution has presented all its witnesses, the defence may submit that there is no case to answer. The arguments are heard outside the presence of the jury and if the submission succeeds, the judge, rather than the jury, acquits the accused. If the submission is unsuccessful, the case simply continues. ${ }^{146}$ In making this decision, the judge should not assess the credibility or reliability of the evidence since these are jury matters; he should simply determine whether the evidence, if accepted, would be sufficient in law for conviction. ${ }^{147}$ It is worth noting that this procedure was unknown in Scotland until it was imported from England in 1980. A s well as the statutory power to withdraw the case from the jury at the close of the prosecution case, the judge also has a common law power, which he may exercise on application or of his own volition, to hold that there is insufficient evidence to allow the case to go to the jury. However, he may do this only after all the evidence has been heard and the closing speeches made. In this eventuality, the judge cannot acquit the accused, but must direct the jury to return a verdict of not guilty. ${ }^{148}$

The Sutherland Committee recently raised the question of whether the judge should be empowered to withdraw a case from the jury or to direct the acquittal "if he believes [the jury] could not reasonably reach a guilty verdict"; the Committee suggested that this matter, which was peripheral to its remit, should be given further consideration. ${ }^{149}$ It added nothing further, but the proposal seems to imply that the judge should make some assessment of the reliability and credibility of the evidence. If so, this is a rather revolutionary proposal because it seems to involve a degree of usurpation by the judge of the jury's role. For example, if, in the judge's opinion, no jury could reasonably believe the main prosecution witness, and there is insufficient other evidence to convict, then the judge should presumably withdraw the case from the jury. A s yet, the government has not taken this matter up, and it seems probable that the proposal will simply be forgotten, largely because of its radical nature.

144. Seeid.

145. Seeid.

146. See Criminal Procedure A ct $\S 97$ (1995) (Scot.).

147. The Scottish requirement that the prosecution evidence must be corroborated is of particular importance in this context. For instance, it might be that the evidence of the victim, although totally convincing, is not corroborated by any evidence from another source, in which case the judge would be bound to accede to the defence application that there is no case to answer and acquit the accused.

148. See K ent v. H. M. A dvocate, 1950 J.C. 38, 39; see also RENTON \& BROWN, supra note 15, ๆ 1876.

149. Sutherland Committee on Criminal appeals and miscarriages of justice PR OCEDURES, 1996, Cmnd. 3245, at 19, 20 [hereinafter CRIM INA L A PPEALS]. I ts deliberations will be further discussed below in Part III.J . 
A t the end of the trial, the prosecutor and defence briefly address the jury, and then the judge directs the jury as to the law. The judge is not required to summarise the evidence, as he is in some jurisdictions, but particularly in a long or complicated trial, he would normally remind the jury of the main points. ${ }^{150}$ When the jury retires to consider its verdict, the clerk of court, acting in practice through a court officer, encloses the jurors in a room by themselves. ${ }^{151}$ If necessary, the jury must be secluded in overnight accommodation. ${ }^{152}$ A part from instructions by the judge in connection with administrative matters-for example, food and accommodation or emergencies- no one may visit the jury room, nor may any juror leave it, except where further directions are sought or given or where the jury asks to examine a production. ${ }^{153}$ The legislation provides that any contravention of these provisions shall lead to the acquittal of the accused. ${ }^{15}$

U nder the Contempt of Court A ct of 1981, which applies both in Scotland and south of the border, it is contempt for anyone to obtain, disclose, or solicit any particulars of the deliberations in the jury room. ${ }^{155}$ Thus, the phenomenon in the $U$ nited States of jurors revealing the secrets of the jury room, sometimes for large sums of money, cannot happen in G reat B ritain. This rigorous approach was implemented in 1981 following revelations in a political weekly by a juror from the trial of a prominent politician for conspiracy to murder, and the subsequent failure of an attempt to prosecute the magazine for contempt. ${ }^{156}$ The major disadvantage of the legislation is that it makes serious research into juries' reasons for their verdicts virtually impossible. For this reason, the recent E nglish R oyal Commission on Criminal J ustice recommended that the A ct be amended to allow research into the process by which jurors reach decisions. $^{157}$ This proposal is still under consideration by the government. ${ }^{158}$

\section{H. The M ajority V erdict}

The Scottish criminal jury may return a verdict, whether for conviction or acquittal, on the basis of a bare majority of eight to seven. ${ }^{159}$ Consequently, there is no such thing as a hung jury; every trial produces a verdict. The jury should be directed by the judge that eight votes are necessary for conviction, and it should not be told to try for unanimity before returning a majority ver-

150. See Shepherd v. H. M. A dvocate, 1997 S.L.T. 525, 528 (H.C.J .).

151. See Criminal Procedure A ct $\S 99$ (1995) (Scot.).

152. See Thomson v. H. M. A dvocate, 1998 S.L.T. 364, 365-66 (H.C.J.).

153. See Criminal Procedure A ct $\S 99$ (1995) (Scot.).

154. Seeid.

155. Contempt of Court A ct $\S 8(c)$ (1) (1981) (Scot.).

156. See A ttorney-General v. New Statesman and Nation Publ'g Co., 1 A II E.R. 644, 646-47, 650 (1980) (holding that the A ttorney G eneral's contempt of court argument was not justified in this particular instance).

157. See nglish ROYA L COMmission On CRIM InA L J USTICE REPORT, 1993, Cmnd. 2263, at 2.

158. See FIRM AND FAIR, supra note 44, ๆ 3.14; see also CRIM INA L A PPEA LS, supra note 149, ๆ 3.7.

159. SeeRENTON \& BROWN, supra note 15 , १ 18-79. 
dict. $^{160}$ In returning the jury's verdict, the foreman must state, or be asked, whether it is unanimous or by majority, but should not be asked for the size of the majority. ${ }^{161}$ The Thomson Committee considered the possibility that the actual numbers of those voting for each of the three verdicts should be announced in open court in order to prevent mistakes. ${ }^{162}$ Because it infringed upon the privacy of the jury room, this option did not find favour with the committee. However, the Committee suggested that the judge might be encouraged to enquire into the voting in order to satisfy himself that the verdict was correct. ${ }^{163}$ M ore recently, in M cC adden v. H. M. A dvocate, the L ord J ustice Clerk suggested that the jurors ought to be asked how many of them voted guilty, ${ }^{164}$ but this was disregarded in practice and disapproved in the subsequent case of Pullar. ${ }^{165}$ Thus, the size of the majority remains a mystery in all cases.

In his history of the Scottish jury, Willock observes that the verdict of the Scottish jury seems always to have been reached by majority vote. ${ }^{166} \mathrm{He}$ suggests that in medieval times, verdicts were reached by taking the sense of the meeting, or the feeling of the community, and that dissent was tolerated but not thought to be of much importance. ${ }^{167}$ Thus, by midway through the sixteenth century, the majority verdict had become formally established as an integral part of trial by jury, encouraging the use of an odd number of jurors, and it also had become established that a majority of one was sufficient to determine the verdict. $^{168}$ In contrast, a firm rule had developed in E ngland by the middle of the fourteenth century, remaining unaltered until very recently, that the verdict must be unanimous. ${ }^{169}$

The adequacy of a bare majority of eight to seven is obviously open to question. This emerges very starkly when one considers that until the abolition of capital punishment in the early 1960s, it was theoretically possible for someone to be executed on the basis of this majority. In essence, is it really safe to convict someone if seven out of fifteen jurors think that the case has not been satisfactorily proven? If almost half of the jurors are not convinced of the accused's guilt, is this not evidence in itself that the case has not been proven beyond reasonable doubt? These questions have been ably analysed by G erry M aher, who argues that the rule of unanimity is not always necessary to show that the principle of proof beyond reasonable doubt is being taken seriously. ${ }^{170}$ In his view, one must take into account other means by which the criminal process attempts

160. Seeid.

161. See Criminal Procedure A ct $\S 100$ (1) (1995) (Scot.).

162. SeeThom SON COMMITTEe, supra note 39, 1 9 51.51-.56.

163. Seeid.

164. 1985 J.C. 98, 103 (1985).

165. Pullar v. H. M. A dvocate, 1993 S.C. (J .C.) 126, 136-37.

166. See WILLOCK, supra note 1 , at 226.

167. Seeid.

168. Seeid.

169. See infra text accompanying note 173 . 52.

170. See Gerry M aher, The Verdict of the J ury, in THE JURY U NDER A TTACK, supra note 37, at 45- 
to ensure proof of guilt at a level of practical certainty. The Scottish system, for instance, demands corroboration of the Crown case and provides the protection of the not proven verdict. ${ }^{171}$ Nevertheless, $M$ aher does question whether conviction by a simple majority does in fact give sufficient weight to the principle of requiring proof beyond reasonable doubt. ${ }^{172}$

Clearly, a practical advantage of the Scottish position is that there is no such thing as a hung trial. H owever, a less obvious point is made by $M$ aher in his critique of the English position. The law in England now requires a majority of ten to two, whether for conviction or acquittal. ${ }^{173}$ Where the jury splits nine to three, there will be a retrial. ${ }^{174}$ A s M aher observes, this does not sit comfortably with the presumption of innocence or with the associated principle of double jeopardy. ${ }^{175}$ The prosecution has had its chance to prove the accused's guilt and has failed; surely the presumption of innocence means that the accused is entitled to be acquitted. A s M aher puts it, "[t]he presumption of innocence therefore closes the logical space between proof of guilt and proof of innocence," and thus where the verdict is not one of guilt, the result must be acquittal rather than a retrial. ${ }^{176}$ This criticism cannot be levelled at the Scottish position.

The majority verdict has been considered on several occasions in recent years. The Thomson Committee canvassed, without much enthusiasm, the possibility that the ratio required for a guilty verdict should be two to one, that is, ten to five or, if the size of the jury were reduced, eight to four, but the overwhelming weight of submissions was in favour of retaining the bare majority. ${ }^{177}$ U Itimately, only one member of the Committee dissented from this view, the remainder arguing that a "weighted" majority was unnecessary in view of other safeguards for the protection of the innocent. The Committee suggested that if its recommendation to reduce the size of the jury to twelve persons were adopted, a seven-to-five majority should be required for conviction and an even split of six to six should lead to acquittal. ${ }^{178}$ The recent Scottish 0 ffice review also sought reaction to a possible increase in the number required for conviction, particularly if the three verdict system were to be abolished. ${ }^{179}$ It cited the arguments both for and against the simple majority, while expressing no opinion on the matter itself. ${ }^{180}$ The government announced that most respondents to this review favoured the straightforward majority, and given that the size of

171. See infra PartIII.I.

172. See $M$ aher, supra note 170 , at $45-52$.

173. Seeid. at 43.

174. Seeid.

175. Seeid. at 50-52.

176. Id. at 50.

177. SeeThom Son COMM ITTEe, supra note 39, 1 १ 51.06-.07.

178. See id. ๆ 51.12. This would not be symmetrical and consequently avoids the practical and theoretical difficulties often posed by the "weighted" majority verdict.

179. See JURIES AND VERDICTS, supra note 43 , ch. 6.

180. Seeid. 
the jury was to remain at fifteen and the three verdict system was to be retained, there was no case for changing the existing position. ${ }^{181}$

Finally, it is worth noting that the abandonment of the unanimity rule in England and its replacement with the requirement of a ten-to-two majority ${ }^{182}$ provoked a great deal of vehement protest. For instance, M.D.A. Freeman claimed that "the concept of a majority verdict strikes at the root of the fundamental principle of English law that guilt must be proved beyond reasonable doubt." ${ }^{183}$ Y et in Scotland, which is ruled by the same government and has a very similar culture, the principle that guilt must be proved beyond reasonable doubt has happily coexisted with the majority verdict for centuries. Further, there are several other jurisdictions where the majority verdict is not thought to prejudice the presumption of innocence, a fact which appears to be ignored by the $\mathrm{E}$ nglish critics of the abandonment of the unanimity rule.

\section{The Three V erdict System}

U ndoubtedly the most peculiar aspect of the Scottish system of trial by jury is that it allows the jury in criminal trials a choice of three verdicts: guilty, not proven, and not guilty. This phenomenon was the result of an historical accident, but it has now formed part of the Scottish criminal justice system for over 250 years. ${ }^{184}$ The verdicts of guilty and not guilty are self-explanatory, but the intermediate verdict of "not proven" requires some elucidation. While there is no common law or statutory definition of "not proven," the vital point is that it has exactly the same effect as a not guilty verdict; it counts as an acquittal. ${ }^{185}$ The difference is that the verdict of "not guilty" is thought to mean that the accused definitely did not commit the crime, that is, it is a positive declaration of innocence, whereas the verdict of "not proven" is thought to imply solely that the accused's guilt has not been conclusively demonstrated. ${ }^{186}$ A s a result of this uncertainty, the Court of A ppeal has discouraged judges from attempting to direct jurors as to the difference between not proven and not guilty, although they must be informed of the three verdicts available to them. ${ }^{187}$ It has also been held that it is not necessary to tell jurors that not proven is a verdict of ac-

181. See FIRM A ND FAIR, supra note 44 , १ 3.20 .

182. See Criminal J ustice A ct $\S 13$ (1967).

183. M.D.A. Freeman, The Jury on Trial, 34 CuRRENT LEgAL PROBS. 65, 69 (1981); see also ENRIGHT \& MORTON, supra note 102, at 75-76; Blake, supra note 37, at 143.

184. See WILLOCK, supra note 1 , at 217-25.

185. A s explained above, where the jury is not unanimous, there must be at least eight votes for conviction in order to convict the accused, and the judge directs the jury to this effect. Where the votes for acquittal are split, the majority of such votes dictates whether the verdict is one of not guilty or not proven, an even split resulting in the latter verdict. See RENTON \& BROWN, supra note 15, 9 18-90. This seems to indicate that if the jury is unsure which verdict to deliver, the judge should enquire into the actual figures, which is difficult to reconcile with the principle that no such enquiry should be made. See also M cCadden v. H. M. A dvocate, 1985 J.C. 98, 103; Pullar v. H. M. A dvocate, 1993 S.C. (J .C.) 126, 136-37.

186. SeeJURIESAND VERDICTS, supra note 43 , at 29.

187. See M CD onald v. H. M. A dvocate, 1989 S.L.T. 289, 299 (H.C.J .). 
quittal, ${ }^{188}$ presumably because they are always told that at least eight votes of guilty are required for conviction and thus can work out the consequences of a not proven verdict for themselves.

Whatever its meaning, there is no doubt that the not proven verdict is used fairly frequently by the Scottish courts. A round one-third of all jury acquittals are the product of the not proven verdict, while the equivalent in nonjury trials is around one-fifth. ${ }^{189}$ The verdict has attracted much criticism over the years, primarily on the ground of its lack of logic. It is argued, quite simply, that if the Crown cannot prove its case beyond reasonable doubt, the only possible verdict should be not guilty. That is dictated by the presumption of innocence, and therefore there is no place for a "second class" acquittal. ${ }^{190}$ D ebate has tended to focus around two main arguments which are usually put forth in favour of the three verdict system. ${ }^{191}$

First, it is claimed that the jury may well not be convinced of the accused's innocence. Of particular significance here is the Scottish rule that the prosecution case must be corroborated. ${ }^{192}$ It is argued that there are many cases where one witness is completely believed, but there is insufficient corroborating evidence to allow the jury, or the judge in a nonjury trial, to convict, although they may be fairly certain that the accused is indeed guilty. ${ }^{193}$ This might be particularly so with regard to the victim of a sexual assault. The Scottish O ffice paper supports this claim by demonstrating that the not proven verdict comprised "a slightly higher proportion" of acquittals in rape and sexual assault cases over a number of years. ${ }^{194}$ In such cases, the not proven verdict is more satisfactory for the victim because it does not necessarily cast doubt upon her honesty or reliability. In response to this argument, it might well be observed that this does not alter the fact that the presumption of innocence demands a verdict of not guilty if the Crown case cannot be proved.

Second, it is claimed that if jurors were faced with a straight choice between guilty and not guilty, they might opt for guilty where otherwise they would have found the case not proven. ${ }^{195}$ In other words, there would be an increased danger of wrongful convictions. The majority of the members of the Thomson Committee were sufficiently worried by this possibility to recommend that the not proven verdict should be retained, although they accepted the argument that the three verdict system was illogical. ${ }^{196}$ In response, it might be observed that, first, their concern is based purely on speculation, and, second, there is al-

188. See M cR ae v. H. M. A dvocate, 1990 J.C. 28, 28-29.

189. See JURIES AND VERDICTS, supra note 43 , at 27-28. Nevertheless, four-tenths of not proven verdicts are returned in nonjury trials as a result of the far greater number of such trials. See id. at 28, tbls. $1,2$.

190. SeeThomson CommitTeE, supra note 39, 151.05 .

191. Seeid. ी 51.05; see also J URIES A ND VERDICTS, supra note 43, ch. 10.

192. SeeRENTON \& BROWN, supra note 15, ๆ 24-69.

193. See JURIESAND VERDICTS, supra note 43, ch. 10.

194. Id. ๆ 10.4, tbl. 3.

195. See id. १1 10.1.

196. SeeThomson Committee, supra note 39 , 951.05 . 
ways a danger of wrongful conviction, yet no other country in the world feels that giving the jury a choice of three verdicts is a solution to this problem.

There is a third possible argument which has not been addressed in the debate over the not proven verdict. A necdotal evidence suggests that the verdict is sometimes used if the jury knows perfectly well that the accused is guilty but thinks that the law needs to be tempered with mercy. The classic example might be the wife who has been battered by her alcoholic husband for years and eventually stabs him to death with the bread-knife as he lies in a drunken stupor on the couch. It is not unknown in such a case for a jury to return a verdict of not proven to a charge of murder, ${ }^{197}$ even in the face of overwhelming evidence, presumably because it sees no purpose in further punishing the accused. In essence, the not proven verdict provides the jury with a rather subtle way of "nullifying" the law instead of having to confront it directly and openly. What the jury is really saying through the medium of a not proven verdict is that while it knows perfectly well the accused is guilty, it is not prepared to convict in this particular case. Given the issues raised by jury "nullification," it is not surprising that this argument has not been officially cited in support of the not proven verdict.

It is worth examining in more detail the most recent controversy over the not proven verdict because it has attracted a great deal of public and political interest. The debate was started by the trial of a young man for the brutal killing of a female student, which, to the astonishment of most observers, resulted in a not proven verdict by the jury. ${ }^{198}$ The media strongly hinted that the accused had indeed committed the crime, and the police gave the impression that as far as they were concerned the matter was closed. ${ }^{199} \mathrm{~W}$ ithin weeks, the victims' parents were organising a petition which demanded the abolition of the not proven verdict, attracting much support and a great deal of media attention. ${ }^{200}$ I mplicit in much of the criticism of the not proven verdict was the belief that were it not available, the jury would have returned a guilty verdict. This, of course, although likely, is impossible to tell. ${ }^{201}$

A round this time, the L ord A dvocate, the senior law officer in Scotland, revealed in an extensive interview with a Sunday newspaper that he felt some "unease" over the not proven verdict. ${ }^{202}$ Nevertheless, he confirmed that nei-

197. The doctrine of provocation would not allow the charge to be reduced to culpable homicide in such a case.

198. For a full account of the debate, see Peter D uff, The Not Proven V erdict: J ury M ythology and "M oral Panics", 41 J U RID. REV . 1, 1-12 (1996).

199. Seeid.

200. For instance, a member of Labour's shadow ministerial team announced he would introduce a Private M ember's Bill to abolish the verdict. See J oy Copley, Bill L aunched to A bolish "Not Proven", SCOTSMA N, A pr. 22, 1993, at 6.

201. See N ot Proven: "That Bastard Verdict" (BBC Scotland television broadcast, Focal Point D ocumentary, M ay 13, 1993) [hereinafter BBC Broadcast]; see also FIRM AND FA IR, supra note 44, at 32.

202. See Kenny Farquharson, L aw Chief Uneasy over "N ot Proven", SCOTLAND ON SUNDAY, Mar. 21,1993 , at 21. 
ther he nor the Scottish Office was persuaded that there was enough dissatisfaction to justify scrutiny of the verdict. ${ }^{203} \mathrm{H}$ owever, the campaign to abolish the not proven verdict continued to gather momentum and, shortly afterwards, the BBC (Scotland) devoted its flagship documentary to the issue, entitling the programme "N ot Proven: 'That B astard V erdict'" (the latter phrase being a description of the verdict by Sir Walter Scott, who hated its illogicality ${ }^{204}$ ). Supporters of the verdict were given an opportunity on the programme to explain their point of view, but the thrust of an emotive programme was essentially hostile to the retention of the three verdict system. Further, the BBC had commissioned a public opinion poll which produced the devastating finding that the majority of the Scottish public, including those who had served as jurors, simply did not understand the not proven verdict or its implications. ${ }^{205}$ $M$ any people erroneously thought that the accused could be retried if more evidence came to light. ${ }^{206}$

A this time, by pure coincidence, the Scottish O ffice was beginning a major review of various aspects of the criminal justice process, the primary motive being to cut costs and increase efficiency. ${ }^{207}$ The government simply added to this review an examination of the not proven verdict along with various other aspects of trial by jury, a pragmatic solution to the increasing political pressure. $^{208}$ A s described above, the Scottish Office consultation paper raised several other issues, including the peremptory challenge, the size of the jury, and the simple majority verdict, but the bulk of the paper was devoted to the not proven verdict. ${ }^{209}$ The government expressed no opinion on its future, but simply canvassed the arguments for and against it and invited the submission of views. $^{210}$

U Itimately, the decision was to retain the not proven verdict. The consultation exercise had not revealed "a consensus for change," either among the legal profession or the public. ${ }^{211}$ Further, the government noted that respondents were divided about the logical case for three verdicts, some asserting that "the three verdicts were entirely logical and, indeed, more consistent with reality

203. Seeid.

204. Q uoted in WILLOCK, supra note 1 , at 217.

205. See B BC B roadcast, supra note 201; see also J URIES A ND VERDICTS, supra note 43, at 31; A listair Bonnington, Third O ption for Scots J uries, HERA LD, M ay 13, 1993, at 15. B ut cf. Lord M cCluskey, Fiddling with Scottish J ustice, SCO LA G 69, 70 (1994); J ohn R obertson \& Iain Duff, Parents $V$ ow to Continue Campaign, SCOTSM A N, J une 28, 1994, at 4 (reporting comments of the Solicitor G eneral).

206. See B BC Broadcast, supra note 201

207. See FIRM AND FAIR, supra note 44 , at 1.

208. See J oy Copley, J ustice System in Scotland Comes U nder Review, ScotSM A N, M ay 26, 1993, at 1.

209. SeeJURIESAND VERDICTS, supra note 43.

210. Seeid.

211. See FIRM A ND FAIR, supra note 44, ๆ 3.16. It is interesting to note that a factor which influenced the Thomson Committee, other than their fear of wrongful convictions, was that "there is no evidence that the public regard the system as working unsatisfactorily." THOM SON COM MITTEE, supra note 39 , ๆ 5.12 . 
than a two verdict system." ${ }^{212}$ Thus, in the absence of "a considerable weight of informed opinion against the three verdict system," the government thought that it should be kept. ${ }^{213}$ R egarding jurors' possible "misconceptions" about the verdict, it was suggested that to some extent these would have been corrected by the consultation paper, ${ }^{214}$ although it is perhaps somewhat optimistic to think that the public makes a habit of reading such papers. There was an assurance in the W hite Paper that the judiciary had taken steps to ensure that juries understand that a verdict of not proven does not lead to a retrial. ${ }^{215}$

\section{J. A ppeal: Perversity of J ury's V erdict ${ }^{216}$}

The right to appeal against conviction under solemn procedure was introduced by the 1926 Criminal A ppeal A ct. ${ }^{217}$ Three grounds were stipulated. The first two were very general: "a wrong decision of any question of law" by the court, and "a miscarriage of justice." ${ }^{218}$ The third ground was more specific, "the verdict of the jury... was unreasonable or cannot be supported having regard to the evidence." ${ }^{219}$ D espite this wording, the A ppeal Court never granted an appeal based solely on the perversity of the jury's decision, only allowing appeals under this heading where the jury's verdict was self-contradictory or illogical in some way. ${ }^{220}$ Thus, any attempt to argue that the jury could not have reasonably convicted on the basis of the evidence was invariably doomed to failure.

These three grounds of appeal were removed and replaced with a single ground- "miscarriage of justice" - by the 1980 C riminal J ustice A ct. ${ }^{221}$ The intention underlying the change was probably to liberalise the attitude of the court, but it did not affect the A ppeal Court's approach to claims that the evidence simply did not sustain the jury's verdict. ${ }^{222}$ In 1984, the Lord J ustice G eneral, Scotland's most senior judge, commented:

Questions of the reliability and credibility of witnesses are essentially, in our law, questions for the jury, and we know of no case in which this court has interfered with any conviction upon the ground that, in its opinion, a jury had been perverse in treating a key witness as both reliable and credible. ${ }^{223}$

212. FIRM A ND FAIR, supra note 44, ๆ 3.17.

213. Id. ๆ 3.19 .

214. See generally id. ๆ $13.15-.19$.

215. Seeid. ๆ 3.18.

216. See LORD M CCLUSKEY, CRIMINAL A PPEALS § 2 (1992) (providing general information on appeals process).

217. See Criminal A ppeal A ct $\S 2$ (1926) (Scot.).

218. Id.

219. Id.

220. See Salmond v. H. M. A dvocate, 1992 S.L.T. 156, 157-58 (H.C.J. Sept. 9, 1990) (appeal was allowed when a jury in an attempted murder case found the accused "guilty ... with extreme provocation," because this verdict was indisputably incompetent since provocation is not relevant to a charge of attempted murder).

221. Criminal J ustice A ct $\S 33$ (1980) (Scot.).

222. SeeRENTON \& BROWN, supra note 15, ๆ 29-07.

223. Rubin v. H. M. A dvocate, 1984 S.L.T. 369, 370-71 (H .C.J.). 
A s the editors of R enton and Brown observe, "the very narrow approach adopted under the old law to factual challenges to jury verdicts has persisted into the new jurisprudence of the court." ${ }^{224}$ It is also useful to note that in his book on appeals, L ord M cCluskey, a H igh Court judge himself, seems doubtful that the A ppeal Court will ever "retreat from the notion ... that the conclusions... of the jury ... are sacrosanct and inviolable whatever the weight and coherence of the evidence." 225

$V$ arious aspects of the appeal procedure were recently examined by the Sutherland Committee, including the question of overturning the jury's verdict. $^{226}$ The Committee agreed with the general principle that the A ppeal Court should be very reluctant to interfere with a jury's verdict reached on the basis of legal sufficiency of the evidence. ${ }^{227}$ It did think, however, that there might be a few "exceptional" cases where "any reasonable jury ought to have entertained a reasonable doubt," and argued that the A ppeal Court should overturn the jury's verdict where that verdict is "unreasonable and has resulted in a miscarriage." ${ }^{228}$ Furthermore, it recommended that this power should be specifically enshrined in statute, presumably because this might help to overcome the court's notorious reluctance to interfere with the verdict of a jury. ${ }^{229}$

However, the Committee did not favour the English A ppeal Court's approach of overturning a jury's verdict on the basis of a "lurking doubt" or "gut feeling," because this would debase the original verdict and might lead to the court being "swamped" with appeals. ${ }^{230}$ Instead, it preferred a more objective test and ultimately, something very close to its suggested formulation was adopted in the Crime and Punishment A ct of 1997. ${ }^{231}$ This formula retains the approach of creating only one ground of appeal-a "miscarriage of justice" but specifically includes within this heading the granting of an appeal for "the jury's having returned a verdict which no reasonable jury, properly directed, could have returned."

In essence, as the Sutherland Committee observed, the issue of overturning an unreasonable verdict "strikes at the heart of the role of the jury in Scottish criminal procedure." ${ }^{233}$ In fact, this subject raises fundamental questions about jury trial in every jurisdiction where the institution exists. The main justification for the jury is that it is alleged to be better at finding the facts than the judge(s) acting alone and, consequently, it is very difficult to justify any judicial interference with the verdict of the jury. To overturn the jury's decision is to

224. RENTON \& BROWN, supra note 15, ๆ 29-07.

225. LORD M CCLUSKEY, supra note 216, at 188.

226. See CRIMINA L A PPEA LS, supra note 149, ๆ $2.59-.71$.

227. See id. १ 2.66

228. Id. ๆ 2.67 .

229. See id. १ 2.68.

230. See id. १ 2.69 .

231. See Crime and Punishment A ct $\S 17$ (1997) (Scot.); see also CRIMINAL A PPEALS, supra note 149, १ 2.70.

232. Crime and Punishment A ct $\S 17$ (1997) (Scot.).

233. CRIM INA L A PPEA LS, supra note 149, ๆ 2.66 . 
demonstrate a lack of faith in the institution, calling its very existence into doubt. That, of course, is why appeal courts in every jurisdiction are much quicker to intervene where there has been some minor procedural hitch than when there is a query over the essential merits of the conviction. Obviously, one can frame the necessary test to review the jury's decision in a variety of ways, but whether one talks of a "lurking doubt," or a "perverse verdict," or "returning a verdict which no reasonable jury could have returned," one is challenging the very raison d'être of trial by jury. For this reason, it seems unlikely that the new provision will make much difference to the approach of the Scottish courts.

\section{K. A ppeal: I rregularity of Procedure and Prejudice}

There is little purpose in listing all the possible irregularities in procedure here. In practice, the most common ground of appeal under solemn procedure is that of misdirection by the judge. ${ }^{234}$ It is clear, however, that most such cases stem from a general dissatisfaction with the verdict and the need of the accused's adviser to find an appropriate "peg" on which to hang an appeal. ${ }^{235}$ A ppeals on the grounds of other types of irregularity affecting the jury are few. ${ }^{236}$ Nonetheless, it is worth discussing allegations that the jury was prejudiced in some way because there have recently been several such appeals, and by their very nature, they go to the very heart of jury trial.

The question of possible prejudice following pretrial publicity has already been considered, and as we saw, an appeal has yet to succeed. A more common allegation is that one or two jurors were biased against the accused for some other reason. In this context, the most influential modern case is probably $\mathrm{McC}$ adden, where, it will be remembered, the A ppeal Court took the opportunity to disapprove of any attempt to vet jurors in any way. ${ }^{237}$ The appeal was based on the allegation that one juror had made remarks in a social club indicating that he was prejudiced against the accused. The appeal was rejected and while the court stated that "it cannot be held that an appeal based on alleged malpractice by a juror ... can never be entertained," it was made very clear that it would be extremely difficult for such an appeal to succeed. A $n$ inquiry into allegations of juror malpractice would be held only where the court was satisfied that "the evidence placed before it to substantiate the claim is prima facie sufficiently substantial, convincing and trustworthy to warrant an inquiry." ${ }^{238}$ In the court's view, there were sufficient safeguards-the judicial direction, the jury of fifteen, the majority verdict, et cetera- to prevent a miscar-

234. Seepeter duff \& Frazer m cCallum, Grounds of A ppeal in Criminal Ca Ses 22, tbl. 7 (1996). In a sample of 250 appeals against conviction under solemn procedure, which produced 350 grounds of appeal, 147 of the grounds related to alleged misdirection by the judge. See id.

235. Seeid.

236. In the sample of 350 appeal grounds, only four related to alleged jury irregularity. See id.

237. See M cCadden v. H. M. A dvocate, 1985 J.C. 98, 102.

238. Id. 
riage of justice. Further, there were obvious "dangers to the administration of justice which would result from a too facile resort" to such inquiry. ${ }^{239}$

The importance that the courts attach to the effect of the judicial direction to consider the case dispassionately, as a counterweight to possible prejudice, can hardly be overstated. In the recent case of G ray V. H. M. Advocate, the A ppeal Court summed up its approach: "It has repeatedly been observed that it must be assumed that jurors will comply with the directions given to them by the presiding judge." ${ }^{40}$ In that case, the judge had stressed that the jury should ignore everything but the evidence of the witnesses given in court. ${ }^{241}$ Despite strong indications that there had been contact during the trial between two jurors and a co-accused, against whom charges were withdrawn, the individuals who were ultimately convicted had their appeal rejected. ${ }^{242}$

O ne further case is worth citing in this context. In Pullar v. H. M. Advocate, ${ }^{243}$ one of the jurors had been an employee of one of the two main prosecution witnesses. He had informed the clerk before the ballot but, on being questioned, had stated he did not know the accused or any of the circumstances of the case. ${ }^{244}$ The clerk took no further action, and the juror was selected. ${ }^{245} \mathrm{~A} \mathrm{f}$ ter proceedings had begun, the prosecution witness also informed the clerk of the relationship, and the clerk assured him that the juror had disclaimed any knowledge of the case. ${ }^{246}$ Hearing an appeal against conviction, the A ppeal Court accepted that the clerk should have passed this information to the judge and that, if this had happened, the juror would have been excused, or at least could have been challenged, because of the possibility of bias. ${ }^{247}$ It rejected the appeal however, because this irregularity did not automatically invalidate the verdict and there was no evidence that the juror was biased or that a miscarriage of justice had occurred. ${ }^{248}$ The accused then unsuccessfully appealed to the E uropean Court of H uman R ights, under A rticle Six of the Convention, on the ground that the jury was not "independent and impartial." ${ }^{249}$ The E uropean Court of Human Rights observed that there was no evidence of bias nor any likelihood in the circumstances that the juror was more likely to believe his employer than the defence witnesses. ${ }^{250}$ Further, the integrity of the jury was protected by various safeguards, primarily the existence of fourteen other ju-

239. Id. It is fair to say that in this case the two witnesses who had allegedly overheard the juror's remarks in the social club were unconvincing; they were not of good character, and they were friends of the accused's brother.

240. 1994 S.L.T. 1237, 1243 (H.C.J.) (emphasis added).

241. See id. at 1241.

242. See id. at 1244.

243. 1993 S.C. (J .C.) 126. Here, the court took the opportunity to establish the procedures for ensuring that jurors do not know the parties to the case.

244. Seeid. at 130.

245. See id.

246. Seeid.

247. See id. at 133.

248. Seeid. at 134.

249. See Pullar v. U nited K ingdom, 1996 S.C.C.R. 755.

250. Seeid. 
rors, the jurors' oath to assess the witnesses dispassionately, and the judicial direction. ${ }^{251}$

\section{IV}

\section{CONCLUSION}

This account of the Scottish criminal jury has, I hope, fulfilled two purposes. First, it has furnished a full description of the institution, and in particular, emphasised its peculiarities- principally its size, the existence of the bare majority verdict, and the rather illogical three verdict system. Second, it has also attempted to challenge, in passing, various common preconceptions about the nature of jury trial. For instance, it should have become clear that the institution of trial by jury does not necessarily require that the accused should have any "right" to have his case put to a jury. Nor need it involve a complex selection procedure, with both sides having plentiful opportunities to challenge potential jurors on the ground of possible bias. Nor, finally, does conviction require unanimity on the part of the jury, or a heavily weighted majority, contrary to what is often thought.

A s we have seen, the Scottish jury has existed for a long time, and without serious challenge, despite the absence of such features which are often regarded elsewhere as integral parts of jury trial. It is quite easy to perceive a particular aspect of jury trial in one's own jurisdiction as a matter of logical necessity or fundamental principle, rather than realising it is the product of mere historical accident. The benefit of this type of collection is that it ought to allow the reader to avoid such ethnocentrism and to appreciate the full range of the institution of trial by jury.

251. Seeid. 